\title{
PANDANGAN HUKUM ISLAM PADA TANTANGAN MODERASI BERAGAMA MASYARAKAT BALI DI TENGAH PANDEMI COVID-19
}

\author{
VIEW OF ISLAMIC LAW ON THE CHALLENGES OF RELIGIOUS \\ MODERATION OF BALI COMMUNITY IN THE MIDDLE OF PANDEMIC \\ COVID-19
}

\author{
Veronica Octavina \\ IAIN Jember \\ Octavina27@gmail.com
}

Moh. Haris Balady

harisbalady@gmail.com

\begin{abstract}
ABSTRAK
Artikel ini akan memfokuskan kajian dan pembahasan pada prinsip-prinsip dan fenomena moderasi Islam di Bali saat pandemi Covid-19. Artikel ini bertujuan untuk mengungkap dan menggambarkan berbagai prinsip bagi moderasi keberagamaan yang telah dirumuskan oleh pakar hukum Islam baik dari kalangan Ushuliyyun maupun Fuqaha. Artikel ini juga bertujuan untuk mengemukakan fenomena-fenomena moderasi Hukum Islam di Bali saat Pandemi COVID-19 yang telah ditunjukkan oleh ulama fiqih Islam dalam tradisi istinbath hukum. Metode yang digunakan dalam penelitian ini ialah kepustakaan. Hasil penelitian menunjukkan bahwa masyarakat Bali yang plural menerapkan sikap moderasi keberagamaan di tengah pandemi Covid-19 yang dihadapi dengan berbagai macam budaya agama yang berbeda.
\end{abstract}

Kata Kunci : Moderasi beragama, Masyarakat Bali, Pandemi COVID-19.

\begin{abstract}
This article will focus the study and discussion on the principles and phenomena of Islamic moderation in Bali during the Covid-19 pandemic. This article aims to uncover and describe the various principles for moderation of di religion that have been formulated by islamic law experts from both Ushuliyyun and Fuqaha circles. This article also aims to present the moderating phenomena of Islamic Law in Bali during the COVID-19 Pandemic that has been demonstrated by Islamic jurisprudence scholars in the tradition of istinbath law. The method used in this study is an ethnographic approach by paying attention to culture (Anthropology) and language (Linguistics). The results showed that the plural Balinese community adopted a moderation attitude of diversity in the midst of the Covid-19 pandemic faced with a variety of different religious cultures.
\end{abstract}

Keywords: Religious moderation, Balinese society, COVID-19 pandemic. 


\section{PENDAHULUAN}

Pandemi COVID-19 yang menjadi sorotan dunia, kini banyak aspek yang dirugikan oleh virus tersebut. Baik itu faktor ekonomi, sosial, politik, budaya dan agama. Bali saat ini memang belum terbebas dari COVID-19. Provinsi ini bahkan masih berada pada jajaran 22 daerah dengan penyebaran yang relatif cepat berdasarkan definisi tingkat produksi virus di atas 1.Perkembangan COVID-19 di Provinsi Bali juga terkendali secara geografis. Dari sembilan kota/kabupaten di provinsi ini, penyebaran dilaporkan oleh pemerintah di provinsi Bali mayoritas terjadi di empat wilayah yaitu Denpasar dengan presentase 22,89 persen atau sekitar 136 kasus, diikuti oleh Buleleng dengan presentase 17 persen atau sekitar 101 kasus, Bangli 16,49 persen atau sekitar 98 kasus, serta Badung 12,1 persen atau sekitar 72 kasus. Sementara itu, di wilayah lain dilaporkan hanya terdapat 20-40 kasus positif.

Sudah sebulan sejak Bali mengimplementasikan fase kedua dari protokol new-normal pada akhir Juli lalu. Sejauh ini, lebih dari 3000 (rata-rata) wisatawan domestik telah mendarat di bandara Bali setiap harinya, jelas Wayan Koster, Gubernur Bali kepada Balipost pada 31 Agustus 2020. Namun, kabar baik ini ternyata kurang berpengaruh signifikan terhadap kondisi tingkat hunian hotel Bali; karena jumlah pengunjung relatif masih sangat rendah jika dibandingkan dengan jumlah kamar hotel di Bali yang lebih dari 130.000.

Wakil Ketua Umum Asosiasi Manajer Umum Hotel Indonesia di Bali, I Made Ramia Adnyana menyampaikan keprihatinannya atas rencana pemerintah pusat Indonesia untuk menutup perbatasan hingga akhir tahun 2020. "... dengan masih adanya empat hingga lima bulan lagi. Kami belum bisa memastikan bagaimana industri pariwisata Bali bisa bertahan hingga awal 2021, "ujarnya. Covid-19 telah menyebabkan banyak pekerja Bali di industri pariwisata kehilangan pekerjaan; kebanyakan dari mereka terpaksa kembali ke desanya untuk bertani atau memancing sekedar hanya untuk bertahan hidup.

Situasi ini diperburuk dengan lonjakan jumlah infeksi baru Covid-19 saat ini. Kemarin, Bali mencatat kasus terkonfirmasi harian tertinggi 129, yang mendorong total kasus menjadi 5207; 68 kematian, 4434 pasien sembuh dan 705 kasus aktif. Meski demikian, angka tersebut masih relatif kecil jika dibandingkan dengan lebih dari 174.796 kasus dan 7.417 kematian di Indonesia.

Awal pekan lalu, Pemprov Bali memberlakukan peraturan baru yang mewajibkan pemakaian masker di tempat umum. Peraturan ini mungkin terkesan serupa dengan arahan sebelumnya yang diberikan oleh pihak pemerintah provinsi pada bulan April. Namun, saat ini semuanya sudah diatur dalam peraturan gubernur nomor 46 tahun 2020, bagi yang tertangkap tidak memakai masker di luar rumah akan dikenakan denda sebesar Rp. 100.000. Bisnis dan tempat/ fasilitas umum juga wajib menyediakan fasilitas sanitasi/ kesehatan, seperti hand sanitizer, tempat cuci tangan, pemeriksa suhu, poster kewaspadaan virus Corona, dan selalu mengingatkan para tamu untuk tetap menjaga jarak sosial. Pelanggaran peraturan 
ini akan dikenakan denda Rp. 1.000.000 atau bahkan pencabutan izin operasionalnya untuk sementara. Pelanggar harus membayar denda kepada petugas di tempat.

Gubernur Bali meyakini kunci pemulihan ekonomi di pulau Dewata hanya akan bisa jika semua masyarakat memiliki disiplin diri dan menaati semua peraturan protokol kesehatan yang sudah ada.

Negara yang dikenal dengan Bhineka Tunggal Ika ini banyak tantangan yang harus dihadapi saat pandemi. Terutama mengenai urusan Ibadah, baik itu umat Islam, Kristen Katolik, Kristen Protestan, Hindu, Budha dan Konghucu, semua agama memiliki batasan tertentu saat beribadah untuk menerapkan protokol kesehatan. Tidak menuntut kemungkinan sikap toleransi antar umat beragama juga tertantang dalam menghadapi hal ini. Toleransi antar umat beragama yang masuk dalam pembahasan moderasi beragama sudah ada beberapa pendapat dari para ulama terutama mengenai isu-isu yang muncul saat pandemi COVID-19 ini.

Indonesia sebagai negara yang memiliki penduduk muslim terbanyak di dunia menjadi sorotan penting dalam hal moderasi Islam. Moderasi adalah ajaran inti agama Islam. Islam moderat adalah paham keagamaan yang sangat relavan dalam konteks keberagaman dalam segala aspek, baik agama, adat istiadat, suku dan bangsa itu sendiri (Dawing, 2017, p. 231).

Oleh karena itu pemahaman tentang moderasi beragama harus dipahami secara kontekstual bukan secara tekstual, artinya bahwa moderasi dalam beragama di Indonesia bukan Indonesia yang dimoderatkan, tetapi cara pemahaman dalam beragama yang harus moderat karena Indonesia memiliki banyaknya kultur, budaya dan adat istiadat.

Moderasi Islam ini dapat menjawab berbagai problematika dalam keagamaan dan peradaban global. Yang tidak kalah penting bahwa muslim moderat mampu menjawab dengan lantang disertai dengan tindakan damai dengan kelompok berbasis radikal, ekstrimis dan puritan yang melakukan segala halnya dengan tindakan kekerasan (Fadl, 2005, p. 343).

Islam dan umat Islam saat ini paling tidak menghadapi dua tantangan; Pertama, kecenderungan sebagian kalangan umat Islam untuk bersikap ekstrem dan ketat dalam memahami teks-teks keagamaan dan mencoba memaksakan cara tersebut di tengah masyarakat muslim , bahkan dalam beberapa hal menggunakan kekerasan; kedua, kecenderungan lain yang juga ekstrem dengan bersikap longgar dalam beragama dan tunduk pada perilaku serta pemikiran negatif yang berasal dari budayadan peradaban lain. Dalam upayanya itu mereka mengutip teks-teks keagamaan (Alquran dan Hadis) dan karya-karya ulama klasik (turats) sebagai landasan dan kerangka pemikiran, tetapi dengan memahaminya secara tekstual dan terlepas dari konteks kesejarahan. Sehingga tak ayal mereka seperti generasi yang terlambat lahir, sebab hidup di tengah masyarakat modern dengan cara berfikir generasi terdahulu (Hanafi, 2013, pp. 1-2). 
Dalam menghadapi masyarakat majemuk, senjata yang paling ampuh untuk mengatur agar tidak terjadi radikalisme, bentrokan adalah melalui pendidikan Islam yang moderat dan inklusif (Alam, 2017, p. 36).

Dalam realitas kehidupan nyata, manusia tidak dapat menghindarkan diri dari perkara-perkara yang berseberangan. Karena itu al-Wasathiyyah Islamiyyah mengapresiasi unsur rabbaniyyah (ketuhanan) dan insaniyyah (kemanusiaan), mengkombinasi antara maddiyyah (materialisme) dan ruhiyyah (spiritualisme), menggabungkan antara wahyu (revelation) dan akal (reason), antara maslahah ammah (al-jamāiyyah) dan maslahah individu (al-fardiyyah) (Almu'tasim, 2019).

Penelitian ini bertujuan untuk menjadikan keberagaman agama sebagai aset yang penting bagi negara Indonesia adalah bagaimana cara moderat yang ditawarkan oleh Islam dapat menjadi pemersatu bagi Indonesia.

\section{METODE}

Penelitian ini merupakan penelitian kepustakaan. Ada empat ciri penelitian kepustakaan, yaitu: 1) penelitian berhadapan langsung dengan teks (naskah) atau data angka dan bukan dengan pengetahuan langsung dari lapangan atau saksi mata (eye witness) berupa kejadian, orang atau benda lainnya, 2) data pustaka bersifat siap pakai (ready mode), 3) data perpustakaan umumnya sumber sekunder dan 4) data pustaka tidak dibatasi oleh ruang dan waktu karena ia sudah merupakan data "mati" yang tersimpan dalam rekaman tertulis. Maka dalam penelitian ini menggunakan penelitian kepustakaan.

\section{HASIL DAN PEMBAHASAN}

Bali memang merupakan wilayah dominan Hindu, namun bukan berarti Bali identik dengan Hindu. Hal ini sama persis ketika menempatkan Indonesia yang memang dengan mayoritas umat Islam, namun tidak secara otomatis mengidentikkan Indonesia dengan negara Muslim (atau bahkan negara Islam). Penduduk Indonesia dan Bali adalah plural, meskipun salah satu penganut agama (umat) memang harus diakui ada yang dominan/mayoritas. Memang, Kebudayaan Bali secara umum hakikatnya dilandasi oleh nilai-nilai yang bersumber pada ajaran agama Hindu, karena mayoritas penduduknya memang beragama Hindu. Ajaran agama Hindu inilah yang akhirnya berpilin dengan kearifan lokal menjelma menjadi sebuah adat sosial kemanusiaan di lokasi ini.

Realitas kearifan lokal (termasuk kearifan lokal pada intra Bali sendiri) ini diyakini betul oleh masyarakat setempat yang mengakui adanya perbedaaan (rwa bhineda), yang terjadi akibat faktor ruang (desa), waktu (kala), serta kondisi/keadaan riil di lapangan (patra). Konsep desa, kala, dan patra inilah yang menyebabkan kebudayaan Bali akhirnya memiliki aneka variasi alias warna-warni. Dengan kata lain, konsep desa-kala-patra ini menjadi landasan pembenar realitas perbedaan adat-istiadat antar wilayah atau malahan antar desa di Bali. Bahkan, pada saat yang sama kebudayaan ini menj adi bersifat fleksibel. (Dhurorudin Mashad, 
2014: 7)

Pandemi koronavirus 2019-2020 telah mempengaruhi penyelenggaraan berbagai kegiatan keagamaan di seluruh dunia. Pengaruh dari pandemi terhadap keagamaan termasuk pembatalan kegiatan peribadatan, pembatalan dan pelarangan kunjungan peribadatan dan perayaan hari besar keagamaan. Para pemuka agama juga memodifikasi serta mengadaptasi beberapa praktek peribadatan yang lazim dilaksanakan sebagai tindakan pencegahan meluasnya pandemi koronavirus 20192020. Langkah pencegahan juga dilakukan dengan penutupan sementara rumah ibadah berbagai agama termasuk gereja, masjid, sangha, pura, kuil dan gurdwara.

Wabah virus corona menyebabkan pengarakan ogoh-ogoh atau patung raksasa yang biasa dilakukan sehari menjelang Nyepi ditiadakan. Tradisi mengarak ogoh-ogoh, seperti yang selalu dilakukan setiap tahun, selalu menjadi peristiwa yang dinanti oleh warga, baik umat Hindu maupun pemeluk agama lain. Pawai ogoh-ogoh tahun ini ditiadakan setelah Gubernur Bali I Wayan Koster mengeluarkan instruksi pelarangan hari Jumat. Selain melarang pengarakan ogohogoh, gubernur Bali juga memerintahkan agar pelaksanaan upacara Melasti, proses penyucian menjelang Nyepi, diikuti maksimal oleh 25 orang.

Padahal, biasanya proses melasti diikuti hampir semua warga adat desa. Pelarangan pawai ogoh-ogoh dan pembatasan jumlah peserta melasti itu keluar setelah gubernur Bali membuat surat edaran bersama dengan Parisadha Hindu Dharma Indonesia (PHDI) Bali dan Majelis Desa Adat. Dalam surat edaran pertama tertanggal 17 Maret 2020 itu, ketiga lembaga ini belum melarang. Seruan masih sebatas imbauan agar pengarakan ogoh-ogoh ditiadakan. Edaran tersebut juga tidak secara spesifik membatasi wilayah pelaksanaan melasti.

Proses melasti biasa dilakukan di tempat-tempat yang dianggap bisa menyucikan. Misalnya pantai, danau, beji (sumber air), dan campuhan (muara beberapa sungai). Selama prosesi melasti, umat Hindu mengarak benda-benda sakral dari pura (pratima) sebagai bagian dari penyucian sebelum melaksanakan Catur Brata Penyepian selama 24 jam saat Nyepi.

Berkaitan dengan hal itu, dalam berita harian Jawa Pos Radar Bali, Aksi membangunkan warga di sahur hari terakhir bulan Ramadhan (bulan malam takbir seperti berita sebelumnya) di Kampung Jawa, Jalan Ahmad Yani, Denpasar, Sabtu 23 Mei 2020 pagi berbuntut panjang.

Setelah video yang menunjukan puluhan orang warga menyalakan smoke bomb dan memukul bedug viral di media sosial, Polresta Denpasar bergerak cepat. Saat itu ada tujuh orang yang diduga ikut dalam aksi tersebut diamankan. Tujuh orang yang diamankan yakni DDA yang berperan memukul bedug; BHR berperan memukul bedug, AK berperan memukul bedug, RDW berperan memukul bedug, SFI berperan memukul bedug dan menyalakan smoke bomb,

SR berperan mengupload video aksi tersebut di media sosial, dan RWN yang ikut berkumpul dalam aksi tersebut. Ketujuh orang tersebut diperiksa intensif 
penyidik Polresta Denpasar pada 24 Mei 2020. Berdasar informasi yang dihimpun Radar Bali, aksi yang dianggap melanggar imbauan pemerintah soal pencegahan penyebaran virus Corona ini dilakukan di Pertigaan Jalan Ahmad Yani Denpasar, Dusun Wanasari, Denpasar. Aksi itu dilakukan sekitar pukul 03.00 pagi. Kejadian bermula saat pemuda dari RT 5 Gang Pura Pasek, lingkungan Wanasari berkumpul di depan showroom Indomobil di Jalan A. Yani Denpasar.

Selanjutnya sekitar pukul 02.30 Wita seorang bernama AND menyuruh HMZ untuk mengambil bedug yang di simpan di rumah kosong depan mushola. Setelah pemuda berkumpul kurang lebih 30 orang, selanjutnya mereka bergerak membangunkan warga untuk sahur sambil berkeliling sampai di depan Masjid Baitur Rahman. Di sana sudah ada beberapa anak muda yang sudah berkumpul dan membangunkan warga yang sahur diiringi bedug. Salah seorang dari antara mereka merekam kegiatan itu lalu mengunggahnya ke media sosial Hingg akhirnya viral.

Kasus tersebut dihubungkan oleh netizen dengan kasus ngaben Sudaji. Penetapan Ketua Panitia Ngaben Desa Sudaji I Gede Suardana oleh Polres Buleleng dan kerumunan massa di Masjid Baiturrahmah Dusun Wanasari Denpasar, Sabtu 23 Mei 2020 lalu tak bisa dipandang sama. Ulah oknum yang menyalakan flare, kembang api, dan menabuh bedug sambil jingkrak-jingkrak bernyanyi tak bisa dinilai apple to apple alias dibandingkan dengan prosesi ngaben yang dipersiapkan sedemikian rupa dalam waktu panjang serta melibatkan aparat berwenang.

Gede Pasek Suardika alias GPS mengingatkan Gubernur Bali I Wayan Koster untuk lebih arif dan bijaksana merespons dua kasus sensitif tersebut. Bukan malah menyebut istilah didramatisir atau dipolitisir saat masyarakat menuntut keadilan serta menyuarakan aspirasinya. "Sebenarnya fakta ini akan saya sampaikan saat pembelaan di persidangan jika kasusnya (Ngaben Sudaji, red) ngotot dilanjut oleh Penyidik Polres Buleleng hingga ke pengadilan. Namun, saya ungkap sekarang ke publik karena banyak yang menempatkan 'apple to apple' (setara, red) kedua peristiwa tersebut. Padahal sangat jauh bedanya," ucap Gede Pasek Suardika alias GPS yang dikutip dalam Radar Bali.

GPS bersama sejumlah rekannya kini membela tersangka I Gede Suwardana di bawah bendera Berdikari Law Office. Kepada Radarbali.id, GPS menekankan prosesi ritual Ngaben Sudaji disiapkan dalam jangka waktu lama dan biaya cukup besar. Menyikapi kondisi wabah Covid - 19 dan prosesi yang sudah setengah jalan tahapan, warga yang ikut ritual ngaben mengadakan pertemuan yang dihadiri semua unsur. Termasuk aparat keamanan dan Satgas Gotong Royong. Dengan mempertimbangkan ketentuan dan keputusan dari Gubernur, MDA, dan PHDI yang ada, akhirnya upacara ngaben diputuskan dilanjutkan.

Dengan catatan protokol kesehatan penanganan wabah Covid-19 dijalankan. "Foto kegiatan pertemuan ini ada. Apa ini namanya bengkung (bandel, red)? Bukankah itu hasil pertemuan setelah menimbang banyak hal dan masukan. Dilakukan dengan niat baik, lebih-lebih adalah ritual suci yadnya," papar GPS. 
Imbuhnya, pelaksanaan ngaben didahului kegiatan penyemprotan desinfektan, baik di lokasi yadnya digelar, bade, dan lainnya. Masker juga dibagikan ke seluruh keluarga dari 7 sawa yang diaben. Aparat keamanan juga hadir ikut membantu kelancaran upacara.

Para pemangku dan keluarga yang ngaben juga mengenakan masker. Kekeliruan yang terjadi adalah soal jumlah. Untuk mengangkat bade (wadah jenazah, red) saja ternyata tak bisa dilakukan oleh 25 orang, melainkan minimal harus 34 orang. Letak geografis yang naik turun juga menyulitkan hal ini. Ketika berjalan juga banyak masyarakat berkerumun ikut menonton menambah jumlah orang. Saat itu aparat keamanan sudah kerja keras ikut mengaturnya. "Jika kemudian setelah ngaben hingga saat ini tidak ada masalah apa soal kesehatan ya wajar karena semua standar penanganan wabah Covid-19 dijalankan. Jika karena lebih 25 lalu penyelenggaranya dijadikan tersangka maka justru yang harus ditanyakan harus di bawah. Angka 25 orang itu dasarnya hukumnya apa?

Apa paham jenis-jenis upacara di Bali yang membuat aturan? Apa pernah negen bade (mengangkat wadah mayat, red) yang buat aturan? Kenapa untuk upacara diatur 25 orang tetapi di pasar tidak diatur? Bahkan pertemuan rapat pemerintah bisa lebih 25 orang? Kenapa kegiatan di luar adat Bali lebih 25 kok dibolehkan, tetapi ngaben Sudaji kok malah dipidanakan?" tanya GPS. GPS menegaskan ngaben merupakan salah satu upacara adat khas Bali yang tidak ada duanya di dunia. "Jika hari ini panitia ngaben dijadikan tersangka, maka jangan samakan dengan kerumunan hura-hura di Kampung Jawa itu.

Di situ tidak ada mengikuti protokol kesehatan penanganan wabah Covid-19 model apapun. Walau sudah berstatus PKM," tandas pria murah senyum itu. "Jangan samakan Ngaben Sudaji dengan kejadian di Kampung Jawa. Beda sekali tata titi sesana yang dijalankan. Jika hari ini kita lihat yang di Sudaji ditersangkakan dan di Kampung Jawa masih diayun sedikit dibela ya itu ranah polisi yang berwenang. Tetapi, sebagai masyarakat kita berhak menilai. Saya yakin masyarakat sekarang tidak bodoh-bodoh amat untuk dibodohi dengan tontonan penegakan hukum model begini.

Sembari kita berdoa, semoga siapapun yang ditugaskan di Bali adalah mereka yang juga mencintai Bali dan budayanya. Bukan hanya mengejar karier dan merugikan Bali," sambung GPS. GPS mengaku bersedia menjadi salah satu Tim Penasehat Hukum tersangka karena diminta untuk mendampingi perjuangan mencari keadilan. "Kebetulan profesi saya sebagai advokat. Saya dampingi dengan prodeo sebagai bagian kecintaan saya menjaga simbol-simbol adat di Bali. Tentu saya berterima kasih dengan berbagai elemen Hindu baik Persadha Nusantara, KMHDI, Peradah, FA KMHDI, Puskor Hindunesia, Cakrawayu, dan lainnya yang terus membantu, mengawal, dan berjuang menjaga martabat upacara adat Bali ini. Juga seluruh masyarakat Bali yang rela ikut menandatangani petisi online Bebaskan Tersangka Ngaben Sudaji yang dibuat Persadha Nusantara. Luar biasa jumlahnya 
terus meningkat," ungkapnya sembari berkata keadilan memang sulit dihadirkan, tetapi harus tetap diperjuangkan.

Kotroversi tersebut saat ini sudah diselesaikan dengan jalan perdamaian antara dua belah pihak. Dalam pembahasan diskusi online yang dilakukan melalui aplikasi zoom dengan ustadz Hafidzul Muhsin selaku Ketua DPW FKDT Provinsi Bali, mengenai moderasi beragama di tengah pandemi COVID-19 ini, mengupas persoalan tersebut dengan sudut pandang moderasi Islam. Sebagaimana yang beliau jelaskan bahwa, "Bali sudah tradisi dalam toleransi antar umat beragama, seperti halnya pengadaan acara pengajian kemudian ada pecalang masyarakat Hindu yang menjaga hal tersebut dan sebaliknya dalam hal keamanan acara”. Beliau juga menjelaskan hal ini juga telah ditetapkan oleh para ulama mengenai penyebutan "orang kafir" dengan "umat non muslim" untuk menjaga keharmonisan antar umat beragama yang ditetapkan oleh para ulama di Indonesia.

Saat itu Ketua Bidang Fatwa Majelis Ulama Indonesia (MUI) dalam Republika.co.id , Huzaimah Tohido Yanggo, menanggapi larangan pengucapan kafir untuk non-Muslim. Larangan terbut adalah salah satu point yang menjadi salah satu hasil bahtsul masail (kajian masalah) dalam Musyawarah Nasional Alim Ulama dan Konferensi Besar Nahdlatul Ulama 2019. Huzaimah berpendapat, di dalam Alquran memang ada penyebutan kafir untuk orang yang berbeda akidah. "Di dalam Alquran, kalau untuk umum manusia seluruhnya, apakah Muslim atau non-Muslim, itu pakai ayyuhannaas (wahai manusia),"

Sementara, dalam konteks Indonesia, lanjut Huzaimah, dari dulu memang tidak ada penyebutan kafir. Bahkan di dalam undang-undang pun tidak ada. Dalam konteks berwarganegara pun, kata dia, selalu dikatakan dengan sebutan nonmuslim untuk merujuk pada orang beragama selain Islam."Kalau kita menyebut ada yang kafir, ada yang mukmin, kan itu di kalangan kita sendiri, misalnya mungkin dalam ceramah atau apa, dan bukan saat sedang bersama mereka (nonmuslim). Huzaimah mencontohkan acara-acara nasional yang dalam sesi pembacaan doa selalu disebutkan bahwa berdoa sesuai keyakinan masing-masing. "Enggak ada dibilang sesuai kafir atau Islam. Dan di acara nasional kan ada macam-macam agama yang hadir," ungkap dia.

Menurut Huzaimah, larangan pengucapan kafir itu tidak ada kaitannya dalam berwarganegara. Sebab di Indonesia, kata dia, ada beberapa agama yang diakui sehingga harus saling menghormati dan saling menghargai. "Tapi tidak disuruh thai kafir'. Enggak ada yang bilang begitu. Hanya disuruh agar mereka kembali ke jalan yang benar. Disuruh bertaubat. Enggak pernah jangan kamu kafir. Hanya diajak supaya kembali ke jalan yang benar, tentu jalan yang benar itu adalah yang sesuai dengan akidah Islam," katanya.

Islam moderat atau yang dimaksud juga Islam Wasathiyyah, berasal dari dua kata yaitu Islam dan "wasathiyyah". Islam sebagaimana yang diketahui adalah agama yang penuh dengan keberkahan, dan agama yang dibawa oleh Nabi Muhammad Saw. Islam merupakan agama mayoritas yang ada di Indonesia dengan 
penduduk terbanyak di dunia saat ini.

Adapun ciri-ciri lain tentang wasathiyyah yang disampaikan oleh Afrizal Nur dan Mukhlis (2016) sebagai berikut:

1. Tawassuth (mengambil jalan tengah), yaitu pemahaman dan pengamalan yang tidak ifrath (berlebih-lebihan dalam beragama) dan tafrith (mengurangi ajaran agama).

2. Tawazun (berkeseimbangan), yaitu pemahaman dan pengamalan agama secara seimbang yang meliputi semua aspek kehidupan, baik duniawi maupun ukhrawi, tegas dalam menyatakan prinsip yang dapat membedakan antara inhira, (penyimpangan,) dan ikhtilaf (perbedaan).

3. I'tidâl (lurus dan tegas), yaitu menempatkan sesuatu pada tempatnya dan melaksanakan hak dan memenuhi kewajiban secara proporsional.

4. Tasamuh (toleransi), yaitu mengakui dan menghormati perbedaan, baik dalam aspek keagamaan dan berbagai aspek kehidupan lainnya.

5. Musawah (egaliter), yaitu tidak bersikap diskriminatif pada yang lain disebabkan perbedaan keyakinan, tradisi dan asal usul seseorang.

6. Syura (musyawarah), yaitu setiap persoalan diselesaikan dengan jalan musyawarah untuk mencapai mufakat dengan prinsip menempatkan kemaslahatan di atas segalanya.

7. Ishlah (reformasi), yaitu mengutamakan prinsip reformatif untuk mencapai keadaan lebih baik yang mengakomodasi perubahan dan kemajuan zaman dengan berpijak pada kemaslahatan umum (mashlahah 'ammah) dengan tetap berpegang pada prinsip al-muhafazhah 'ala alqadimi al-shalih wa al-akhdzu bi al-jadidi alashlah (melestarikan tradisi lama yang masih relevan, dan menerapkan hal-hal baru yang lebih relevan).

8. Aulawiyah (mendahulukan yang prioritas), yaitu kemampuan mengidentifikasi hal ihwal yang lebih penting harus diutamakan untuk diterapkan dibandingkan dengan yang kepentingannya lebih rendah.

9. Tathawwur wa Ibtikar (dinamis dan inovatif), yaitu selalu terbuka untuk melakukan perubahan-perubahan kearah yang lebih baik. Demikianlah konsep yang ditawarkan oleh Islam tentang moderasi beragama di Indonesia, sehingga konsep tersebut diharapkan mampu untuk diterapkan dalam kehidupan bernegara dan berbangsa. Sehingga dengan konsep moderasi ini akan membawa Indonesia ke arah yang lebih baik, tidak ada diskriminasi dalam keberagaman.

Dengan begitu masyarakat islam memiliki strategi khusus untuk penguatan intelektual keagamaan melalui pendidikan moderasi Islam terhadap generasigenerasi Islam. Memperkuat ajaran washathiyyah di kalang masyarakat Islam untuk menanamkan sikap toleran terutama antar umat beragama di lingkungan masyarakat plural Denpasar, Bali. 


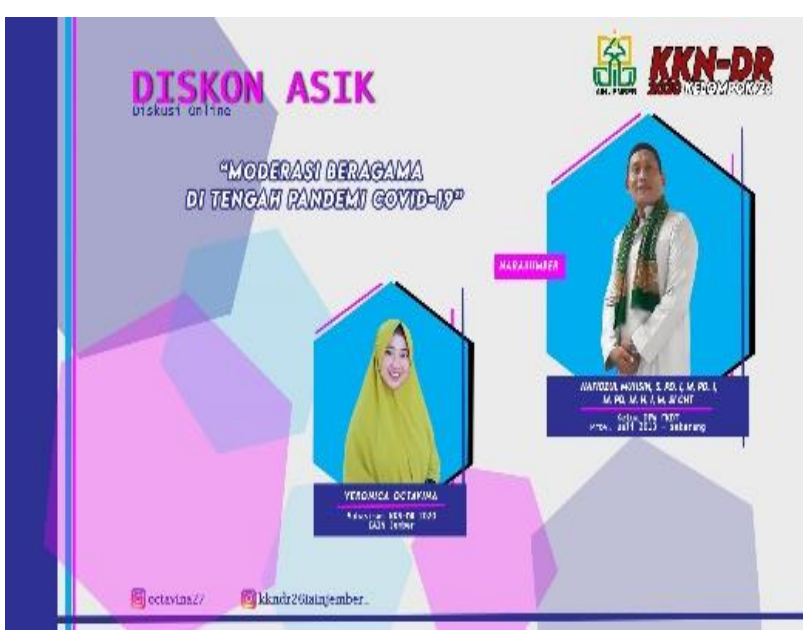

Gambar. 1. Poster Diskusi Online

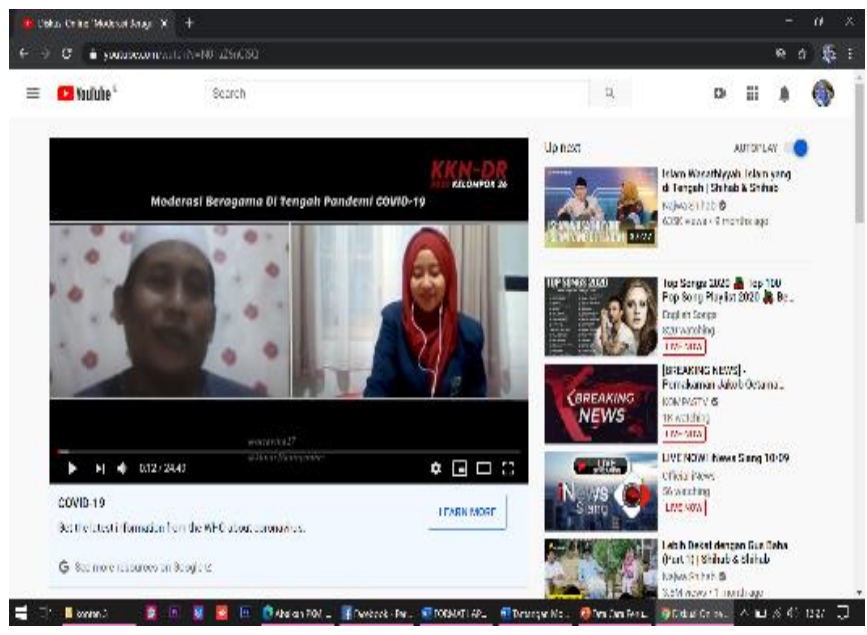

Gambar. 2.

Diskusi Online bersama Ustadz Hafidzul Muhsin (Ketua DPW FKDT Prov. Bali

Seperti yang dikatakan ustadz Hafidzul Muhsin, bahwa para ulama sebelumnya sudah menerapkan sikap moderat yang mengimplementasikannya melalui toleransi antar umat beragama. Seperti halnya pengucapan kafir yang diganti dengan kata non muslim. Dalam hal ini Islam membuktikan sebagai agama yang rahmatan lil 'alamin, rahmat bagi seluruh alam, agama kedamaian, agama yang membawa ketentraman.

Islam mengajak kepada umatnya untuk selalu menjalin kehidupan yang harmonis antara sesama umat manusia. Agama Islam merupakan agama yang penuh dengan toleransi. Toleransi dalam Islam bukan hanya terdapat dalam ajaran 
secara tekstual, tetapi juga telah menjadi karakter dan tabiat hampir seluruh umat Islam dari zaman Muhammad SAW sampai sekarang ini.

Toleransi dalam Islam sudah ada sejak dulu, yaitu sejak zaman nabi Muhammad SAW sampai sekarang. Kebenaran toleransi antar umat beragama dalam Islam seharusnya tidak diragukan lagi apalagi dengan adanya bukti-bukti yang telah diuraikan. Dengan data-data tersebut tergambarlah bahwa sikap lapang dada umat Islam, baik yang ditunjukkan oleh Rasulullah, para sahabat serta para pejuang Islam ketika menyiarkan agama Islam yang berhadapan dengan agama lain sangatlah tinggi, sebab meskipun mereka dihina atau disakiti mereka tetap tenang saja dan selalu bersikap ramah tamah terhadap orang yang menyakitinya itu.

Hal inilah yang membuat orang-orang non Muslim tertarik dan kagum dengan agama Islam, yang akhirnya membawa mereka untuk ikut dan memeluk agama yang dibawa oleh nabi Muhammad saw. Dan membuktikan bahwa agama Islam itu tidak disiarkan dengan jalan kekerasan dan peperangan.

Adanya toleransi antar umat beragama dalam Islam ini juga telah dijelaskan dalam al-Qur'an dan al-Hadits, yang keduanya merupakan pedoman hidup bagi umat Islam, yang berisikan petunjuk dari Allah SWT berupa larangan yang harus dihindari dan kewajiban yang harus dikerjakan oleh umat Islam.

Toleransi mengandung pengertian kesediaan menerima kenyataan pendapat yang berbeda-beda tentang kebenaran yang dianut. Dapat menghargai keyakinan orang lain terhadap agama yang dipeluknya serta memberi kebebasan untuk menjalankan apa yang dianutnya.

Toleransi antar umat beragama dapat diwujudkan dalam bentuk Saling menghormati, memberi kebebasan kepada pemeluk agama lain dalam menjalankan ibadah sesuai dengan agama dan kepercayaannya, dan saling tolong-menolong dalam hidup bermasyarakat.

Meskipun demikian antar umat beragama dapat diwujudkan sebagaimana tersebut di atas, tetapi bukan berarti dalam melaksanakan toleransi ini dengan mencampur adukkan antara kepentingan sosial dan aqidah. Dalam melaksanakan toleransi ada batasan-batasan tertentu. Menurut Ali Machsum (Rais' Aam Nahdlatul Ulama) :

"Batasan toleransi itu ada menurut keyakinannya masing-masing. Islam menghormati orang yang beragama Kristen, Budha, Hindu dan agama lainnya. Bukan karena dia Kristen, Budha atau Hindu tapi Islam menghormati mereka sebagai umat Allah. Ciptaan Allah yang wajib dikasihi. Islam mewajibkan untuk saling menghormati sesama umat beragama, tapi akan murtad kalau dengan itu membenarkan agama lain......" (Hasanuddin, $1420 \mathrm{H}$ : 42).

Dari pendapat yang disampaikan oleh Ali Machsum, tentang batasan toleransi ini, membuktikan gambaran bahwa umat beragama bertoleransi dan menghormati orang lain (umat beragama lain) itu dengan tidak memandang apa agama yang dipeluk oleh orang tersebut melainkan dengan melihat bahwa dia adalah umat Allah 
atau ciptaan Allah yang wajib dikasihi dan dihormati sebab sebagai umat beragama dan umat manusia wajib saling meghormati dan mengasihi.

\section{SIMPULAN}

Kompleksitas kehidupan keagamaan masyarakat Indonesia khususnya, yang sangat plural dan multikultural, telah memicu lahirnya fenomena beragama yang juga kompleks terutama ditengah pandemi COVID-19 ini. Segala aspek diuji baik bidang sosial, budaya, ekonomi, dan agama. Di satu sisi ada yang ekstrem liberal, di sisi lain ada yang ekstrem konservatif dalam praktik beragama. Jika tidak ada kontra narasi moderasi yang diarusutamakan, maka konservatisme, ekstremisme, dan liberalisme dalam beragama bisa dianggap sebagai benar belaka. Padahal, esensi berbagai ajaran agama, seperti telah dibahas dengan sangat gamblang, adalah moderat, dan sangat menekankan upaya untuk merawat harkat dan martabat kemanusiaan. Pandemi COVID-19 ini menguji rasa kemanusiaan seberapa besar yang diterapkan oleh masyarakat.

Kasus di kampung jawa Denpasar Bali yang diusut dalam rasa ketidak adilan yang dirasakan oleh umat agama Hindu. Maka dalam hal ini umat islam perlu adanya pendidikan karakter akhlakul karimah untuk kemaslahatan masa depan generasi selanjutnya yang menanamkan rasa kedamaian di lingkungannya.

Namun, yang paling penting adalah bahwa saat ini kita sedang menemukan momentum yang tepat untuk melakukan penguatan moderasi beragama, termasuk melalui pelembagaannya pada level negara. Kita harus memanfaatkan momentum tersebut, kesempatan sering tidak datang dua kali. Tentu saja, upaya penguatan moderasi beragama adalah tugas kita bersama negara, individu, masyarakat, tokoh agama, budayawan, akademisi, kaum milenial, dan media harus bersatu padu menyosialisasikan dan mengampanyekannya, demi kepentingan kita bersama dalam merawat kerukunan dan kehidupan keagamaan yang damai dan toleran.

\section{DAFTAR PUSTAKA}

Suharto, Babun, et.al. 2019. Moderasi Beragama: Dari Indonesia untuk Dunia. Yogyakarta: LKiS.

Gunawan, Wawan, dkk (ed). 2015. Fikih Kebinekaan, Pandangan Islam Indonesia tentang Umat, Kewargaan, dan Kepemimpinan Non Muslim. Jakarta: Maarif Institut dan Mizan.

Hanafi, Muchlis (ed). 2017. Moderasi Islam. Jakarta: Lajnah Pentashihan Mushaf Alquran, Badan Litbang dan Diklat Kementerian Agama RI.

Hasanuddin, A.H. Cakrawala Kuliah Agama, Al Ikhlas, Surabaya, 1402 H.

Irfan Salim, "Islam dan Akulturasi Budaya Lokal", dalam http://media. isnet.org/islam/gtc/Akulturasi.html, didownload 7/9/2020.

Genik, Lusius. "Peran Pendekatan Keagamaan Masyarakat Bali dalam Menangani Pandemi Covid-19”. www.tribunnews.com/corona/2020/09/05/peranpendekatan-keagamaan-masyarakat-bali-dalam-menangani-pandemi-covid- 
$\underline{19}$, didownload 7/9/2020.

Mus. "Abaikan PKM, Netizen Bali Protes Malam Takbir Pemuda Kampung Jawa, Netizen Bandingkan Dengan Kasus Ngaben Suradji”.

https://radarbali.jawapos.com/read/2020/05/24/195822/abaikan-pkm-netizen-bali-

protes-malam-takbir-pemuda-kampung-jawa, didownload 7/9/2020.

https://instagram.com/octavina27?igshid=82pfueynglia

https://www.youtube.com/channel/UCCJgpN0eaX9CuRd0T6eg-ig 
Veronica Octavina, Moh. Haris Baldy

Pandangan Hukum Islam Pada Tantangan Moderasi Beragama Masyarakat Bali

46 | Pusat Pengabdian Kepada Masyarakat LP2M IAIN Jember 